\title{
Do stable carbon isotopes of brown coal woods record changes in Lower Miocene palaeoecology?
}

\author{
I. Poole $^{\mathrm{a}, \mathrm{b}, *}$, M. Dolezych ${ }^{\text {c,d }}$, J. Kool ${ }^{\mathrm{a}}$, J. van der Burgh ${ }^{\mathrm{d}}$, P.F. van Bergen ${ }^{\mathrm{a}, 1}$ \\ a Geochemistry, Earth Sciences, Utrecht University, P.O. Box 80021, 3508 TA Utrecht, The Netherlands \\ b Palaeontological Museum, Oslo University, P.O. Box 1172 Blindern, N-0318 Oslo, Norway \\ ${ }^{\mathrm{c}}$ Hoyerswerda 02977, Schlossstr. 1c, Germany \\ ${ }^{\mathrm{d}}$ Laboratory of Palaeobotany, Faculty of Biology, University of Utrecht, Budapestlaan 4, 3584 CD Utrecht, The Netherlands
}

Received 24 August 2004; received in revised form 1 November 2005; accepted 11 November 2005

\begin{abstract}
Stable carbon isotope ratios of fossil wood from the Miocene brown coal deposits in former East Germany are compared with palaeobotanical and sedimentological data to test the use of stable isotopes in determining palaeoenvironment. Significant differences in the chemical composition of samples from different horizons were observed. Those specimens preserved under the most (bio)degrading conditions yielded stable carbon isotope values least representative of original wood specimens. Overall, the chemical preservation of the wood was seen to affect the stable isotope signal but deconvolving the preservational bias using a

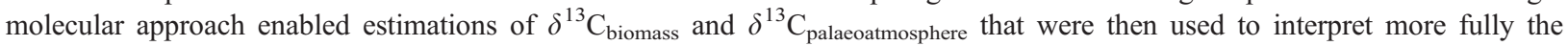
palaeoenvironment.
\end{abstract}

(C) 2005 Elsevier B.V. All rights reserved.

Keywords: Fossil wood; Miocene; Stable carbon isotopes; Pyrolysis; Lignin

\section{Introduction}

$\delta^{13} \mathrm{C}$ values of biomass and atmosphere derived from fossil terrestrial material are important prerequisites for carbon models concerned with constraining carbon flow and understanding terrestrial palaeoecosystems more fully (Poole et al., 2004). Such $\delta^{13} \mathrm{C}$ values rely on the assumption that their isotopic compositions have not been significantly altered during diagenesis. Stable carbon isotope ratios of plant biomass (i.e.

* Corresponding author. Geochemistry, Earth Sciences, Utrecht University, P.O. Box 80021, 3508 TA Utrecht, The Netherlands. E-mail address: i.poole@geo.uu.nl (I. Poole).

${ }^{1}$ Current address: Shell Global Solutions International, Badhuisweg 3, $1031 \mathrm{CM}$ Amsterdam, The Netherlands. $\left.\delta^{13} \mathrm{C}_{\text {biomass }}\right)$ are dependent upon a number of factors: isotopic composition of the atmosphere (e.g. Farquhar et al., 1989), carbon fixation pathway $\left(\mathrm{C}_{3} v\right.$. $\mathrm{C}_{4}$; Smith and Epstein, 1971), and internal assimilation, metabolism and biosynthetic pathways (e.g. O'Leary, 1981; Farquhar et al., 1989). Moreover local environmental parameters such as irradiance, temperature, soil water, salinity influencing water availability also affect the $\delta^{13} \mathrm{C}$ signatures.

With respect to fossil material, additional factors need to be considered. Inherent alterations in $\delta^{13} \mathrm{C}_{\text {fossil plant }}$ signature can arise due to taphonomical processes selectively removing certain chemical moieties thus biasing the $\delta^{13} \mathrm{C}_{\text {fossil plant }}$ value of the organ under investigation. This process has been termed 'chemical taphonomy' (van Bergen and Poole, 2002). Therefore to ensure that 
the $\delta^{13} \mathrm{C}_{\text {fossil plant }}$ values are both as reliable as possible and comparable, the fossils need to be systematically identified, the same organ type targeted and the molecular preservation of each piece of material determined. In addition, whenever possible larger fossil wood samples containing several growth rings are preferred because local environmental factors, such as light and water availability, that influence stomatal conductance and photosynthesis, and as such $\delta^{13} \mathrm{C}_{\text {biomass, }}$, are integrated allowing larger scale isotope trends to be observed. Moreover it is emphasised that the stable carbon isotope composition of the material used here is an integrated time average because lignin-cellulose of one growth ring in living trees also includes carbon fixed during the autumn prior to early wood formation. Moreover, the use of several growth rings into a single sample further reduces seasonally induced changes allowing larger scale isotope trends to be observed.

Despite these boundary conditions, stable carbon isotope values of fossil remains have great potential to help in the reconstruction of palaeoenvironments (e.g. Nguyen Tu et al., 1999, 2002) although direct correlations with $p \mathrm{CO}_{2}$ are more difficult to assess (Nguyen Tu et al., 2004). However, it is necessary to test the variations in $\delta^{13} \mathrm{C}$ values of fossil plants in different deposits in which the environments are already well documented to fully validate this use of carbon isotopes as a tool to characterise changes in palaeoecosystems (Nguyen Tu et al., 2002).

In this paper the use of stable carbon isotopes of fossil material from a well-defined Miocene swamp environment as a palaeoecological indicator is explored by comparing these data with the sedimentological and palaeobotanical conclusions drawn for the sedimentary setting under investigation. The current study focuses on organically well-preserved wood from the Miocene brown coal mines of Wetro, Jänschwalde and Welzow of former East Germany.

The solvent insoluble part of wood, which constitutes the bulk of the material, between $90 \%$ and $96 \%$, is composed of two main chemical moieties: holocellulose (i.e. hemicellulose and cellulose) and lignin. The moieties comprising the cellulose fraction of wood are ${ }^{13} \mathrm{C}$ enriched when compared with the lignin fraction (e.g. Benner et al., 1987; Spiker and Hatcher, 1987; Loader et al., 2003). Therefore the relative abundance of cellulose to lignin preserved within a piece of fossil wood will affect the $\delta^{13} \mathrm{C}_{\text {fossil wood }}$ value. It is well known that under natural anaerobic conditions the holocellulose fraction of wood is preferentially degraded relative to lignin with hemicellulose degrading faster than cellulose (e.g. Benner et al., 1987; Hedges et al.,
1985). Consequently hemicellulose can last for perhaps thousands of years whereas cellulose can survive millions of years. Lignin however can still be recognised after 10s, if not 100s of millions of years (e.g. van Bergen et al., 2004) perhaps not as an original lignin fraction but as degradation products specific to lignin. The selective removal and alteration of the chemical composition are interrelated with the sedimentary environment (van Bergen et al., 1994) and thus preservation type of the fossil.

The depositional environment in the Lusatian region offers a number of fossiliferous localities, namely the Wetro, Jänschwalde and Welzow coal mining areas, which have yielded a wealth of fossil plant material. Most of the plant material has been systematically identified and these results have been used along with sedimentological (Standke et al., 1992), stratigraphical (Göthel, 2002) and palynological studies (Krutzsch, 1992, 2000) to piece together detailed palaeoenvironmental and palaeofloral reconstructions (e.g. Mai, 2000). The material from this region is of interest because the temperature did not vary significantly and water availability appeared to be the only influential factor over this narrow stratigraphic interval spanning approx. 500,000 years during the Lower Miocene about 15-16 Ma ago.

\section{Material and methods}

\subsection{Geological and palaeobotanical context}

The sections sampled are located in the southeastern corner of former East Germany (Fig. 1). They comprise a series of intercalated sand, clay and brown coal layers representing a number of regression/transgression cycles (Göthel, 2002; TB 2.3 and TB 2.4 sensu Haq et al., 1988). The main coal layers are indicated as Bank 1 to Bank 3. The section represents the upper part of the Lower Miocene/lower part of the Middle Miocene, with the top of the sequence situated below evidence of the Ries impact, indicating that the specimens must be at least $15 \mathrm{Ma}$ old (Langhian), with the oldest sequence approximately $16 \mathrm{Ma}$. Based on stratigraphic comparisons the sections correlate to zone M5-M6 based on planktonic foraminifera (Berggren et al., 1995).

All three Banks comprise distinctive facies, ' $\mathrm{K}-\mathrm{A}-\mathrm{G}-$ $\mathrm{P}-\mathrm{M}$ ' corresponding to vegetation succession (Schneider, 1978). According to Göthel (2002) a transgression occurred during the deposition of sediments representing Bank 3 and Bank 1. Bank 2 shows the possible beginnings of a regression but is subsequently truncated by a hiatus. These facies represent vegetation succession 


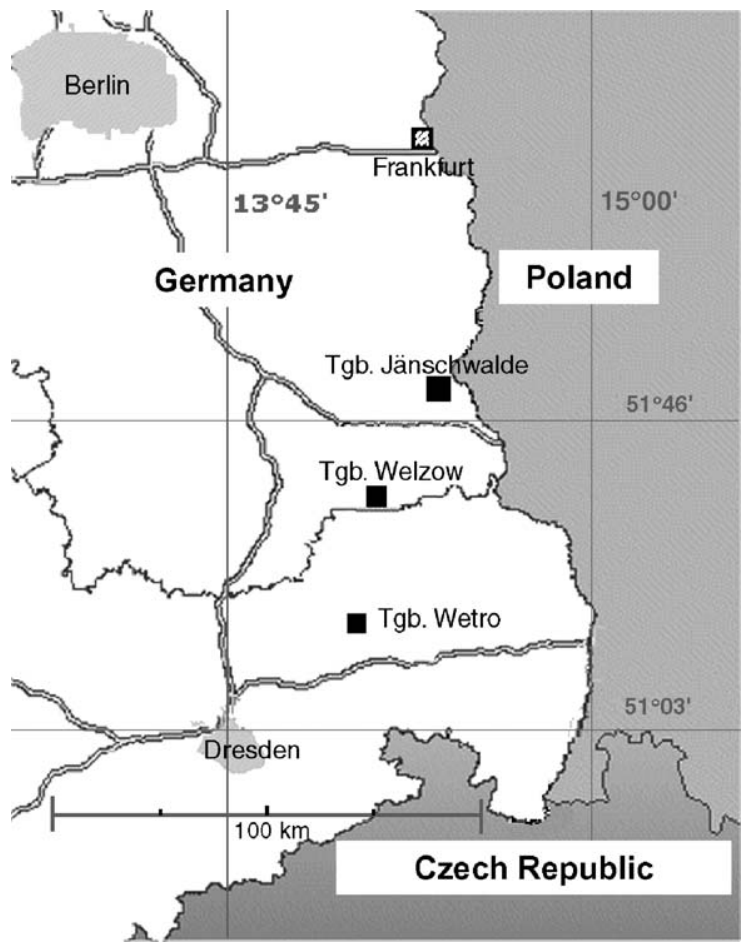

Fig. 1. Locations of the three brown coal mines (Tgb.) from where the samples used in this study originated.

sequences on moorland grading from a species rich (succession/colonizer; ' $\mathrm{K}$ ') vegetation growing on a relatively nutrient poor substrate to a species poor (climax; 'M') vegetation growing on an extremely nutrient poor substrate (Schneider, 1969, 1978, 1992). The time interval for this cycle is in the region of c. $10 \times 10^{3}$ years.

The K-facies represents an eutrophic swamp facies mostly dominated by conifers such as Glyptostrobus (i.e. Glybtostroboxylon) and the slow growing (i.e. 120 rings per $10 \mathrm{~cm}$ ) Sequoia (i.e. Taxodioxylon) forming an open canopy environment. A-facies represents a facies dominated by angiospermous trees and shrubs, e.g. Symplocos, associated with conifers such as the arborescent Taiwania and Cunninghamia. G-facies or Glumiflorae facies yields no wood but only 'grass' fragments, e.g. Cyperaceae and Poaceae, are found here. P-facies or Pinus facies is dominated by conifer woodland composed of trees and shrubs with an understorey of angiosperms. M-facies or Marcoduria facies is extremely nutrient poor and acidic with microorganisms unable to break down the organic matter rendering the wood material relatively well-preserved. The vegetation was open, slow growing and also dominated by conifer trees such as Sciadopitys, Cryptomeria and Sequoia. Marcoduria is characterised by thick spongy roots and associated with dry periods (Schneider, 1969, 1978, 1992).

Vegetation studies (Mai, 2000) of the leaf flora in particular suggest that a floral complex of the "Wiesa" type prevailed over this region under a subtropical/ warm temperate humid, seasonal climate similar to those growing today in the evergreen broad leaved forests of Changsa and Hunan in China. The mean annual temperature is estimated as being at least $18{ }^{\circ} \mathrm{C}$, with an average coldest month temperature of $+4{ }^{\circ} \mathrm{C}$, an absolute minimum temperature dropping to $-5^{\circ} \mathrm{C}$, and a mean annual precipitation of $800-2000 \mathrm{~mm}$ with few to no dry periods during the summer months (Mai, 2000). There are no lithological differences between the localities and the prevailing climate remained constant over this geological time period. Fluctuations in the water table, however, had an effect on the nutrient availability. The underlying clay layers are nutrient rich indicating a flood plain environment dominated by forest, rather than woodland vegetation, which is in accordance with the in situ fossil plants found (Schneider, 1969, 1992).

\subsection{Analyses}

The autochthonous fossil wood samples, 21 conifers and 1 angiosperm, were collected from different coal seams of clearly determined facies (Table 1). No samples were collected near the erosional settings known to occur in these localities (Göthel, 2002).

\subsubsection{Anatomical analyses}

The material was identified by preparing tangential and longitudinal sections of all samples using razor blades and subsequently mounted in glycerine jelly and studied under transmitted light microscopy. One specimen (120701/28) was identified as an angiosperm (Symplocoxylon kräuselii) and the remainder were conifers (see Table 1 and Dolezych, 2005).

\subsubsection{Molecular analyses}

The molecular composition of the woods was determined using the technique of van Bergen and Poole (2002) and Poole and van Bergen (2002). In all cases the wood studied comprised samples from trunk or large branch wood each containing several growth rings and thereby reducing small-scale intra-tree chemical and isotopic variations. The material was powdered and solvent extracted using methanol $(3 \times)$, methanol/ dichloromethane $(3 \times)$ and dichloromethane $(3 \times)$. After each extraction step the sample was centrifuged and the supernatant removed. The final solvent extracted resi- 
Table 1

Fossil wood specimens studied along with their taxonomic assignment and relative abundances of cellulose products (SP), lignin products (LP) and lignin degradation products (LDP), expressed as a percentage, and associated $\delta^{13} \mathrm{C}_{\text {fossil wood, }}, \delta^{13} \mathrm{C}_{\text {levoglucosan }}$ and $\delta^{13} \mathrm{C}_{\text {biomass }}$ arranged from the top of Bank 1 to the underlying clay

\begin{tabular}{|c|c|c|c|c|c|c|c|c|c|}
\hline Sample no. & Locality & $\% \mathrm{SP}$ & $\%$ LP & $\%$ LDP & $\delta^{13} \mathrm{C}_{\text {fossil wood }}$ & $\delta^{13} \mathrm{C}_{\text {levogluc. }}$ & $\delta^{13} \mathrm{C}_{\text {biomass }}{ }^{\mathrm{a}}$ & Taxonomic affinity & Nearest living equivalent \\
\hline 31799 & Welzow $1 \mathrm{M}$ & 97 & 3.5 & 0.5 & -22.2 & -17.1 & -23.6 & Taxodioxylon gypsaceum & Sequoia sempervirens \\
\hline $280502 / 18$ & Welzow $1 \mathrm{M}$ & 98 & 1.5 & 0.5 & -21.7 & ND & -23.1 & Pinuxylon zobelianum & Pinus section cembrae \\
\hline $120701 / 24$ & Welzow $1 \mathrm{M}$ & 90 & 9 & 1 & -22.6 & -21.4 & -23.7 & Pinuxylon tarnocviense & Pinus section strobus \\
\hline $120701 / 27$ & Welzow 1P & 65 & 34 & 1 & -25.6 & -24.9 & -25.5 & Pinuxylon parryoides & Pinus section parrya \\
\hline $120701 / 28$ & Welzow 1P & 25 & 45 & 30 & -27.3 & -24.1 & -25.7 & Symplocoxylon kraeuselii & Symplocos sp. \\
\hline $120701 / 36$ & Welzow 1A & 95 & 3 & 2 & -23.6 & -22.0 & -24.9 & Taxodioxylon gypsaceum & Sequoia sempervirens \\
\hline $120701 / 188$ & Welzow $1 \mathrm{~K}$ & 95 & 4 & 1 & -22.4 & ND & -23.7 & Glyptostroboxylon rudolphii & Glyptostrobus sp. \\
\hline $280502 / 39$ & Welzow $1 \mathrm{~K}$ & 98 & 1 & 1 & -22.1 & -20.1 & -23.5 & Glyptostroboxylon rudolphii & Glyptostrobus sp. \\
\hline $280502 / 9$ & Welzow $1 \mathrm{~K}$ & 98 & 2 & 0 & -22.0 & -24.0 & -23.4 & Juniperoxylon pachyderma & Taxodiaceae cf. \\
\hline $120701 / 49$ & Welzow $2 \mathrm{M}$ & 95 & 4 & 1 & -24.4 & -19.9 & -25.7 & Pinuxylon parryoides & Pinus section parrya \\
\hline $120701 / 121$ & Welzow $2 \mathrm{~K}$ & 98 & 1.5 & 0.5 & -22.5 & -21.1 & -23.9 & Taxodioxylon germanicum & Sequoia sempervirens \\
\hline $291001 / 25$ & Jänschwalde $2 \mathrm{~K}$ & 90 & 8 & 2 & -23.5 & -12.5 & -24.6 & Glyptostroboxylon rudolphii & Glyptostrobus sp. \\
\hline $291001 / 47$ & Jänschwalde $2 \mathrm{~K}$ & 50 & 35 & 15 & -23.7 & -15.4 & -23.1 & Taxodioxylon gypsaceum & Sequoia sempervirens \\
\hline $301001 / 236$ & Jänschwalde $2 \mathrm{~K}$ & 95 & 4 & 1 & -22.4 & -21.6 & -23.7 & Taxodioxylon germanicum & Sequoia sempervirens \\
\hline $120701 / 130$ & Welzow 3P & 30 & 40 & 30 & -25.4 & -20.8 & -24.0 & Pinuxylon parryoides & Pinus section parrya \\
\hline $301001 / 285$ & Jänschwalde $3 \mathrm{P}$ & 5 & 65 & 30 & -24.1 & -15.0 & -21.6 & Pinuxylon parryoides & Pinus section parrya \\
\hline $120701 / 147$ & Welzow $3 \mathrm{~K}$ & 5 & 45 & 50 & -23.3 & -9.8 & -21.0 & Glyptostroboxylon rudolphii & Glyptostrobus sp. \\
\hline $130302 / 218$ & Welzow $3 \mathrm{~K}$ & 0 & 30 & 70 & -24.8 & ND & -22.5 & Glyptostroboxylon rudolphii & Glyptostrobus sp. \\
\hline $301001 / 265$ & Jänschwalde $3 \mathrm{~K}$ & 2 & 49 & 49 & -23.0 & $-3.3^{\mathrm{b}}$ & -20.6 & Taxodioxylon germanicum & Sequoia sempervirens \\
\hline $301001 / 246$ & Jänschwalde $3 \mathrm{~K}$ & 5 & 60 & 35 & -23.7 & -20.6 & -21.3 & Glyptostroboxylon rudolphii & Glyptostrobus sp. \\
\hline MD1 & Wetro Clay & 95 & 3.5 & 1.5 & -23.2 & -19.4 & -24.5 & Taxodioxylon gypsaceum & Sequoia sempervirens \\
\hline MD2 & Wetro Clay & 95 & 3.5 & 1.5 & -23.1 & -25.6 & -24.4 & Taxodioxylon gypsaceum & Sequoia sempervirens \\
\hline
\end{tabular}

$\mathrm{ND}$, not determined.

${ }^{\mathrm{a}} \delta^{13} \mathrm{C}_{\text {biomass }}$ is based on $\delta^{13} \mathrm{C}_{\text {fossil wood }}$ but corrected for its chemical composition (see Eq. (1)).

${ }^{\mathrm{b}}$ Value might be affected by the low relative abundance of levoglucosan in this sample. 
due was air-dried. All residues, containing the insoluble organic matter representing the bulk of the wood, were stored dry in the dark. Approximately $300 \mathrm{mg}$ of each sample was subject to off-line pyrolysis $\left(1 \mathrm{~h}, 300{ }^{\circ} \mathrm{C}\right)$ and the pyrolysis products released were collected using a cold trap. These products were derivatised using an excess of $\mathrm{N}, \mathrm{O}$-bis(trimethylsilyl)-trifluoroacetamide containing 1\% trimethylchlorosilane (BSTFA+ $1 \%$ TMCS) and pyridine and analysed using a HewlettPackard (HP, Wilmington, DE, USA) 6890 gas chromatograph (GC) (see Poole and van Bergen, 2002 for details). Derivatised compounds were identified using a HP 5890 series II GC coupled to a Fisons Instruments VG platform II mass spectrometer (GC/MS; Manchester, UK). Identification was based on mass spectral characteristics and data presented in the literature (Poole and van Bergen, 2002). The holocellulose-, lignin- and lignin degradation products were derived from the relative intensities of each product on the GC chromatogram.

\subsubsection{Stable carbon isotope analysis and corrections}

On-line bulk stable carbon isotope $\left(\delta^{13} \mathrm{C}_{\text {fossil wood }}\right)$ analyses were performed on the extracted wood material using a Fisons Instruments NA 1500 Elemental Analyser (EA). The $\mathrm{CO}_{2}$ released was flushed through the ConFlo II interface and analysed using a Finningan MAT Delta Plus isotope ratio mass spectrometer (IRMS).

Corrected biomass and palaeoatmospheric $\delta^{13} \mathrm{C}$ values were obtained using measured $\delta^{13} \mathrm{C}_{\text {fossil wood }}$ value and the relative abundances of the preserved molecular components (Poole et al., 2004) according to the following equations:

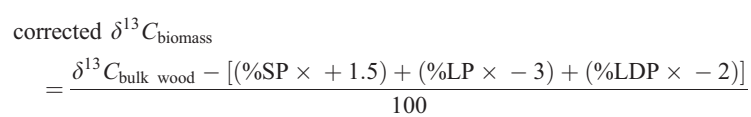

Where \%SP denotes the relative abundance of the cellulose products, LP of lignin products and LDP lignin degradation products; +1.5 is the fractionation factor for cellulose (Leavitt and Long, 1986; SassKlaassen et al., 2004; assuming little hemicellulose contribution to the total holocellulose fraction preserved), -3 is the fractionation factor for lignin (Spiker and Hatcher, 1987) and -2 is the fractionation factor for lignin plus subsequent degradation (i.e. demethoxylation; Galimov, 1985; Spiker and Hatcher, 1987; see Poole et al., 2004 for details).

$\delta^{13} C_{\text {atmosphere }}=$ corrected $\delta^{13} C_{\text {biomass }}+18$
Where 18 is the average fractionation factor for plant material derived from Polley et al. (1993), Arens et al. (2000) and Gröcke (2002) (see Poole et al., 2004 for further details). Again it is emphasised that the $18 \%$ is a first average approximation that can be refined when more detailed studies have been undertaken using welldefined sample sets. Also a difference in fractionation factor between angiosperms and gymnosperms is known (Stuiver and Braziunas, 1987). However, the set of samples used contained only one angiosperm wood specimen, thereby minimizing this taxonomic effect.

\subsubsection{Compound specific stable carbon isotope analysis}

The derivatised compounds released during off-line pyrolysis were subsequently analysed for their stable carbon isotope composition (Poole et al., 2004). Compound specific stable carbon isotope values were measured using a ThermoFinigan Delta PLUS XL GC-combustion-IRMS with similar chromatographic conditions as the GC/MS analysis. Only the values of levoglucosan, the main pyrolysis product of cellulose, are presented. Values represent averages of two analyses with analytical errors typically $<0.8 \%$ o based on standards. Corrections for the TMS groups were determined from derivatised myo-inisitol with an underivitised $\delta^{13} \mathrm{C}$ value of $-26.7 \%$.

\section{Results and discussion}

\subsection{Anatomical and molecular preservation}

From microscopy studies, Bank 1 yielded the best preserved material whereas Bank 3 was the least well preserved evidenced by the relative amount of decay having affected the anatomy and morphology. Within Bank 3 the fungal and bacterial decay have resulted in the characteristic yellowing of the wood or "Gelbfäule". The Taxodiaceae are the most resistant to this decay but even within the Taxodiaceae the K-facies material shows the greatest evidence for decay whereas the Mfacies exhibits the least affected material.

Wood contains approximated $90 \%$ to $96 \%$ solvent insoluble ligno-cellulose with the remainder being solvent soluble compounds such as lipids, resins, oils etc. The average holocellulose and lignin contribution to modern ligno-celullose is approx. $65 \%$ and $35 \%$, respectively (Sarkanen and Ludwig, 1971). When correcting for the effects of chemical taphonomy on the molecular composition of the fossil wood a holocellulose: lignin ratio of c. $65: 35$ yields a corrected value, $\delta^{13} \mathrm{C}_{\text {biomass, }}$, 
almost identical to the measured $\delta^{13} \mathrm{C}_{\text {fossil wood value }}$ (Table 1). For the majority of the samples, cellulose derived products (predominantly levoglucosan) are the main compounds released by off-line pyrolysis (Fig. 2a; Table 1). Samples with relatively high lignin and/or lignin degradation products and little cellulose products (Fig. 2b) originate mainly from Bank 3 (P- and $\mathrm{K}$-facies). In Bank 1, material from the P-facies also shows some chemical degradation whilst in Bank 2 only one specimen from the $\mathrm{K}$-facies reveals a higher degree of molecular degradation. Neither Bank 1 nor 2 specimens show degradation to the extent seen in the material from Bank 3. This attests to an increase in (microbial) degradation of the holocellulose component. This could be brought about through enhanced oxygen exposure times of the organic matter in Bank 3 either (a) during deposition, or (b) post-deposition. Lower water availability of the substrate could have resulted in a decrease in the relative anoxia of the environment leading to enhanced decomposition at the time when the plant was growing/just died. Post-

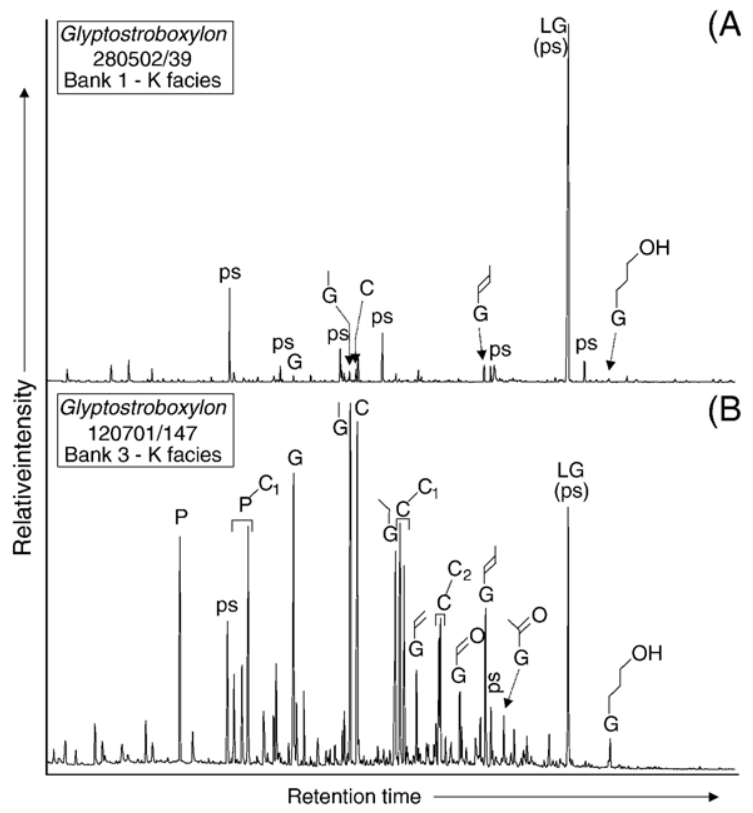

Fig. 2. Total ion chromatograms of the on-line pyrolysates (Curie temperature $610{ }^{\circ} \mathrm{C}$ ) of two wood specimens, Glyptostroboxylon, from the brown coal deposit Welzow: (A) specimen from Bank 1 dominated by polysaccharide pyrolysis products (ps), predominantly levoglucosan (LG), and (B) a specimen from Bank 3 dominated by lignin ( $\mathrm{G}$ compounds) and lignin degradation ( $\mathrm{P}$ and $\mathrm{C}$ compounds) pyrolysis products. Key: ps, polysaccharide pyrolysis products; LG, levoglucosan; Lignin pyrolysis products include G, guaiacol, Lignin degradation products include $\mathrm{P}$, phenol, and $\mathrm{C}$, catechol. Side chains indicated are attached at carbon number 4 para to the $\mathrm{OH}$ group. $\mathrm{C}_{1}$ methyl isomers, $\mathrm{C}_{2}$ dimethyl or ethyl isomers. depositional diagenetic overprinting caused by oxidation could be related to down-cutting of river channels at a later time, for which sedimentological evidence exists (cf. Fig. 2 in Göthel, 2002). This would have led to the samples either being (a) re-exposed to the atmosphere, (b) exposed to an input of oxygenated water related to the erosion channels, or (c) exposed to a decrease in ground water levels. Other samples that have lignin products as the dominant fraction are $120701 / 27$ and 120701/28 both from P-facies of Bank 1 and 291001/47 from K-facies Bank 2, which also could have been subject to similar processes (Table 1). However, since none of the specimens were sampled from the vicinity of obvious erosion channel systems re-exposure to the atmosphere appears, in this instance, to be the least likely cause.

These molecular data are in accordance with the anatomical observations clearly showing the more degraded state of the P- and K-facies samples and the overall enhanced degradation of Bank 3 specimens when compared with those of Bank 1 and 2. Moreover the best-preserved material, in terms of molecular composition, are the Taxodioxylon specimens, which also agrees with the anatomical conclusions.

\subsection{Systematic identity, $\delta^{13} C_{\text {fossil wood }}$ and $\delta^{13} C_{\text {levoglucosan }}$ values}

The $\delta^{13} \mathrm{C}_{\text {fossil wood values measured for the fossil }}$ material ranged from $-21.7 \%$ o to $-27.3 \%$ o (Table 1 ). The most negative value relates to the angiosperm, Symplocoxylon, which is in accordance with the known taxonomic isotopic differences between angiosperms and conifers (Stuiver and Braziunas, 1987). The within-genus variation is relatively small for Taxodioxylon $(1.4 \%$ ), relatively large for Glyptostoboxylon (2.6\%) and appears to be much greater for Pinuxylon $(3.8 \%$ ). These variations are similar or smaller than those reported for conifer material from the Hambach brown coal area (Lücke et al., 1999). This implies that additional factors affect the bulk isotopic signatures to a greater degree than can simply be explained by taxonomic variation. With respect to the $\delta^{13} \mathrm{C}_{\text {levoglucosan }}$ values which can be considered representative for cellulose, these yield an even larger range than the $\delta^{13} \mathrm{C}_{\text {fossil wood values. In general, most values measured }}$ are less negative when compared with the corresponding $\delta^{13} \mathrm{C}_{\text {fossil wood }}$ values, which agrees with the fact that cellulose is less ${ }^{13} \mathrm{C}$ depleted than bulk wood (e.g. Spiker and Hatcher, 1987; Benner et al., 1987). The samples from Bank 3 are rather distinct as they show the least negative values and also show the least pre- 


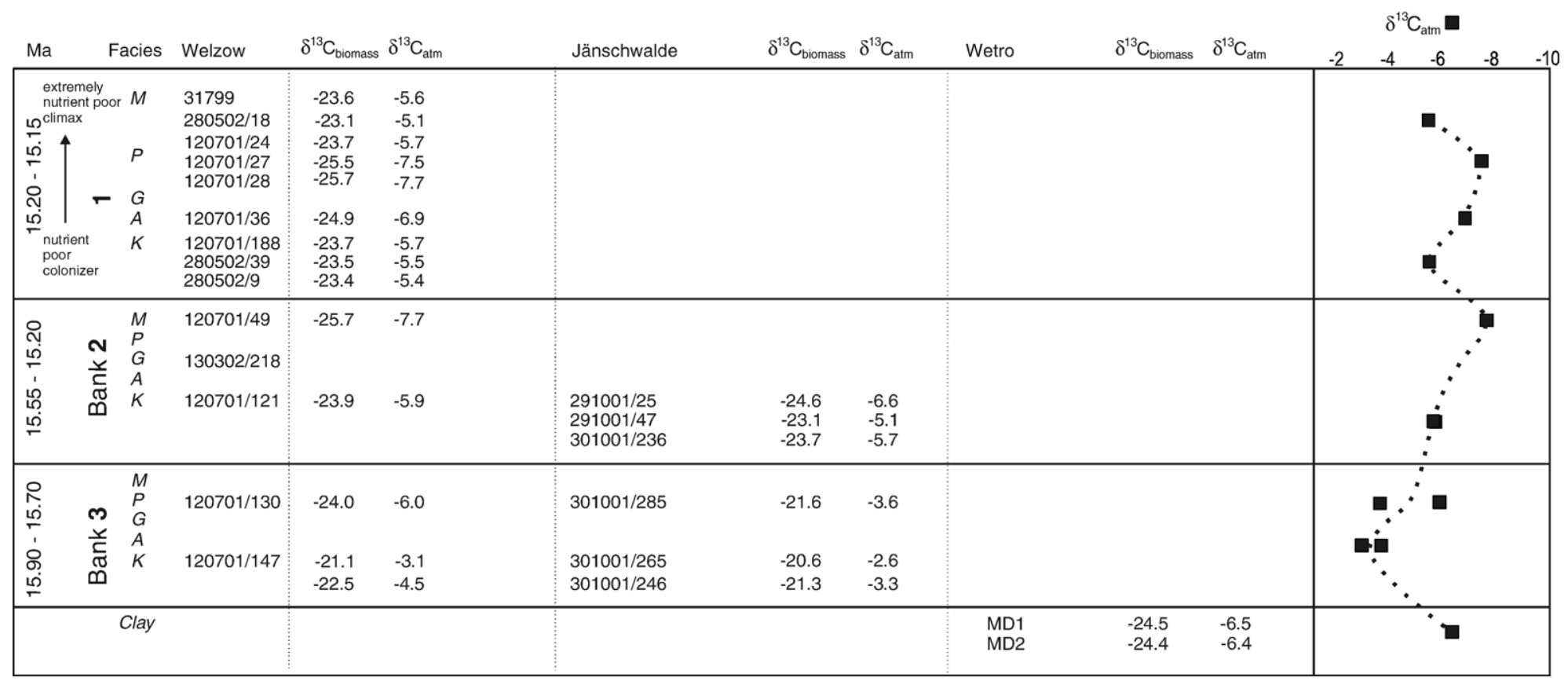

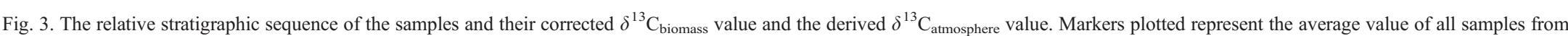
the same facies from the same site. 
served cellulose. This therefore indicates that the lignin formed during this period must be particularly ${ }^{13} \mathrm{C}$ enriched in contrast to "average" lignin, which is generally more ${ }^{13} \mathrm{C}$ depleted.

\section{3. $\delta^{13} C_{\text {biomass }}$ values}

The $\delta{ }^{13} \mathrm{C}_{\text {fossil wood }}$ values obtained for each specimen were corrected according to Eq. (1) above to take into account molecular differences. In principle the corrected values, yielding $\delta^{13} \mathrm{C}_{\text {biomass }}$ (Table 1; Fig. 3), provide more representative bulk wood signatures for the original living plant material than those measured because of the effect of chemical taphonomy, i.e. a chemical composition similar to normal ligno-cellulose will yield $\delta^{13} \mathrm{C}_{\text {biomass }} \approx \delta^{13} \mathrm{C}_{\text {fossil wood }}$ whereas fossil woods dominated by lignin will yield $\delta^{13} \mathrm{C}_{\text {biomass }}>\delta^{13} \mathrm{C}_{\text {fossil wood. }}$

The most complete section is within Bank 1. After correcting for the effects of chemical taphonomy the samples from equivalent facies show similar $\delta^{13} \mathrm{C}$ values that seem to imply facies related differences. Even though Banks 2 and 3 are not as complete, within-facies consistencies are also observed in these Banks.

Nutrient levels are known to affect the bulk $\delta^{13} \mathrm{C}$ values of plant material (Huang et al., 1999). That research showed that increased nitrogen levels resulted in a ${ }^{13} \mathrm{C}$ enrichment in Betula pendula seedlings. The succession of decreasing nutrients from K-facies through to M-facies of Bank 1 of the Welzow locality resulted in more ${ }^{13} \mathrm{C}$ depleted values for the samples from K- through to P-facies - an equivalent trend to that observed by Huang et al. (1999).

The trend to more depleted values through the succession is also observed in Banks 2 and 3 of the Welzow locality. However, the M-facies of Bank 1, supposedly the most nutrient poor facies (Dolezych, 2005), exhibits less depleted values relative to the underlying P-facies. The reason for this is as yet unclear. In the Jänschwalde and Welzow localities the corrected isotopic values of both Banks 1 and 2 are, in general, very similar. In contrast, despite the dominance of the isotopically depleted lignin component, Bank 3 yields notably ${ }^{13} \mathrm{C}$ enriched corrected values, suggesting a difference in environment and/or atmosphere when compared with Banks 1 and 2. These more enriched values in $\delta^{13} \mathrm{C}_{\text {biomass }}$ are to a larger extent also

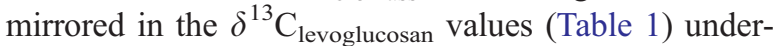
pinning the true change to less depleted values in the organic matter of these trees at the time they actually grew.
In Bank 3 of Jänschwalde locality there is no obvious indication of a nutrient related trend hence only atmosphere or environmental factors will have affected the values. The environment could have been subject to changes, for example fluctuations in water table and thus could have affected the water availability of the trees. Enhanced water use efficiency normally yields more ${ }^{13} \mathrm{C}$ enriched biomass. However, it has been implied that the environmental factors remained constant which discounts this suggestion (Krutzsch, 1992; Mai, 2000; Schneider, 1992). We are aware that the absolute changes in $\delta^{13} \mathrm{C}$ are relatively small and within the natural within tree variation. However, the distinct off-set of approximately $3 \%$ for 5 of the 6 samples from Bank 3 does appear to imply a trend. Thus we believe that the most the likely explanation is a change in atmospheric ${ }^{13} \mathrm{C} /{ }^{12} \mathrm{C}$ ratio (see below).

\section{4. $\delta^{13} C_{\text {atmosphere }}$ values}

When the $\delta^{13} \mathrm{C}$ of the atmosphere is calculated using Eq. (2) it is not surprising that fluctuations identical to those exhibited by $\delta^{13} \mathrm{C}_{\text {biomass }}$ are observed. Within Banks 1 and 2 the shifts in the $\delta^{13} \mathrm{C}_{\text {atmosphere }}$ curve are likely to be environmentally related thus rendering the perceived atmospheric trend nutrient dependent since Eq. (2) is directly dependent upon Eq. (1). However, in Bank 3 no direct evidence of an environmentally related shift is observed. Thus the $3 \%$ o enrichment in $\delta^{13} \mathrm{C}_{\text {atmosphere }}$ when compared with Banks 1 and 2 appears to represent a shift in the atmospheric $\delta^{13} \mathrm{C}$. This shift is in accordance with a change from less to more depleted $\delta^{13} \mathrm{C}$ values as observed in the marine $\delta^{13} \mathrm{C}_{\text {carbonate }}$ curves spanning the Lower to Middle Miocene (e.g. Woodruff and Savin, 1991; Pagani et al., 1999). Once again we would like to emphasise that these observations are a first approximation indicating a trend in the $\delta^{13} \mathrm{C}_{\text {atmosphere values. Further }}$ studies on fossil wood specimens from the same region within the same time interval will validate our initial observations.

\section{Conclusions}

For many years bulk stable carbon isotopes of organic matter have been used to determine carbon flow in the biogeosphere. This in turn has been instrumental in revealing shifts in the $\delta^{13} \mathrm{C}$ of the atmosphere, a factor often associated with changes in atmospheric $\mathrm{CO}_{2}$ both in the present and during the geological past. This study has focused on the use of $\delta^{13} \mathrm{C}_{\text {bulk }}$ values of wood through a time- and sedimentologically 
constrained sequences where any changes in $\delta^{13} \mathrm{C}_{\text {bulk }}$ wood can be related to changes in the environment. By eliminating the biases associated with chemical taphonomy, whereby certain moieties with the own isotopic signature are preferentially lost over time, real, as opposed to perceived, shifts in $\delta^{13} \mathrm{C}_{\text {biomass }}$ could be determined. By understanding the sedimentological and botanical inputs associated with these sections perceived changes in $\delta^{13} \mathrm{C}_{\text {atmosphere }}$ derived from $\delta^{13} \mathrm{C}_{\text {bulk }}$ can be linked to nutrient availability within the environment for two of the Banks but seems to reveal a directional trend in the atmospheric $\delta^{13} \mathrm{C}$ during the time of deposition of the underlying Bank 3. Therefore, chemical preservation and taxonomic identity of fossil material are important prerequisites to understanding real, as opposed to perceived, isotopic shifts and such shifts can provide further details pertaining to the ecology during the geological past.

\section{Acknowledgements}

We would like to thank T. Zalm, G. Nobbe, B. van Os, A. van Dijk and M. Kienhuis for technical assistance. Three anonymous reviewers are thanked for their comments on earlier versions of this manuscript. This work was funded in part by NWO grant number ALW/ 809.32.004 which is greatly appreciated.

\section{References}

Arens, N.C., Jahren, A.H., Amundson, R., 2000. Can C3 plants faithfully record the carbon isotopic composition of atmospheric carbon dioxide? Paleobiology 26, 137-164.

Benner, R., Fogel, M.L., Sprague, E.K., Hodson, R.E., 1987. Depletion of ${ }^{13} \mathrm{C}$ in lignin and its implications for stable isotope studies. Nature 329, 708-710.

Berggren, W.A., Kent, D.V., Swisher, C.C., Aubry, M.-P., 1995. A revised Cenozoic geochronology and chronostratigraphy. In: Berggren, W.A., Kent, D.V., Aubry, M.-P., Hardenbol, J. (Eds.), Geochronology, Time Scales and Global Stratigraphic Correlation, Society for Sedimentary Geology, vol. 54, pp. 129-212. Tulsa.

Dolezych, M. 2005. Koniferenhölzer im 2. Miozänen Lausitzer Flöz und ihre Ökologische Position. LPP Contributions Series No. 19, $\mathrm{PhD}$ thesis, Utrecht University. $339 \mathrm{pp}$.

Farquhar, G.D., Ehleringer, J.R., Hubick, K.T., 1989. Carbon isotope discrimination and photosynthesis. Annu. Rev. Plant Physiol. Plant Mol. Biol. 40, 503-537.

Galimov, E.M., 1985. The Biological Fractionation of Isotopes. Academic Press, Orlando.

Göthel, M., 2002. Die Seese Sande des Mittel-Miozäns der Lausitz Ablagerungen einer Tsunami? Natur. Landsch. Niederlausitz 22, $1-8$.

Gröcke, D.R., 2002. The carbon isotope composition of ancient $\mathrm{CO}_{2}$ based on higher-plant organic matter. Philos. Trans. R. Soc. Lond., A $360,633-658$
Haq, B.U., Hardenbol, J., Vail, P.R., 1988. Mesozoic and Cenozoic chronostratigraphy and cycles of sea-level change. In: Wilgus, C.K., Hastings, B.S., Ross, C.A., Posamentier, H., Wagoner, J., Kendall, C.G.C. (Eds.), Sea-Level Changes: An Integrated Approach, Soc. Economic Paleontol. Mineral. Spec. Pub., vol. 42, pp. $71-108$.

Hedges, J.I., Cowie, G.L., Ertel, J.R., Barbour, R.J., Hatcher, P.G., 1985. Degradation of carbohydrates and lignins in buried woods. Geochim. Cosmochim. Acta 49, 701-711.

Huang, Y., Eglinton, G., Ineson, P., Bol, R., Harkness, D., 1999. The effects of nitrogen fertilisation and elevated $\mathrm{CO}_{2}$ on the lipid biosynthesis and carbon isotopic discrimination in birch seedlings (Betula pendula). Plant Soil 216, 35-45.

Krutzsch, W., 1992. Paläobotanische Klimagliederung des Alttertiärs (Mitteleozän bis Oberoligozän) in Mitteldeutschland und das Problem der Verknüpfung mariner und kontinentaler Gliederungen (klassische Biostratigraphien — paläobotanisch-ökologische Klimastratigraphie - Evolutions-Stratigraphie der Vertebraten). N. Jb. Geol. Paläont. Abh. 186 (1-2), 137-253.

Krutzsch, W., 2000. Stratigraphische Tabelle Oberoligozän und Neogen (marin-kontinental). Berliner Geowiss. Abh. E 34, 153-165.

Leavitt, S.W., Long, A., 1986. Stable carbon isotope variability in tree foliage and wood. Ecology 67, 1002-1010.

Loader, N.J., Robertson, I., McCarroll, D., 2003. Comparison of stable carbon isotope ratios in the whole wood, cellulose and lignin of oak tree-rings. Palaeogeog. Palaeoclimatol. Palaeoecol. 196, 395-407.

Lücke, A., Helle, G., Schleser, G.H., Figueiral, I., Mosbrugger, V., Jones, T.P., Rowe, N.P., 1999. Environmental history of the German Lower Rhine embayment during the Middle Miocene as reflected by carbon isotopes in brown coal. Palaeogeog. Palaeoclimatol. Palaeoecol. 154, 339-352.

Mai, D.H., 2000. Die untermiozänen Floren aus der Spremberger Folge und dem 2. Flözhorizont in der Lausitz Teil IV: Fundstellen und Paläobiologie. - Palaeont. Abt. B 254, 65-176.

Nguyen Tu, T.T., Bocherens, H., Mariotti, A., Baudin, F., Pons, D., Broutin, J., Derenne, S., Largeau, C., 1999. Ecological distribution of Cenomanian terrestrial plants based on ${ }^{13} \mathrm{C} /{ }^{12} \mathrm{C}$ ratios. Palaeogeog. Palaeoclimatol. Palaeoecol. 145, 79-93.

Nguyen Tu, T.T., Kvaček, J., Uličný, D., Bocherens, H., Mariotti, A., Broutin, J., 2002. Isotope reconstruction of plant palaeoecology. Case study of Cenomanian floras from Bohemia. Palaeogeog. Palaeoclimatol. Palaeoecol. 183, 43-70.

Nguyen Tu, T.T., Kürschner, W.M., Schouten, S., van Bergen, P.F., 2004. Leaf carbon isotope composition of fossil and extant oaks grown under differing atmospheric $\mathrm{CO}_{2}$ levels. Palaeogeog. Palaeoclimatol. Palaeoecol. 212, 199-213.

O’Leary, M., 1981. Carbon isotope fractionation in plants. Phytochemistry $20,553-567$.

Pagani, M., Artur, M.A., Freeman, K.H., 1999. Miocene evolution of atmospheric carbon dioxide. Paleoceanography 14, 273-292.

Polley, H.W.M., Johnson, H.B., Marino, B.D., Mayeux, H.S., 1993. Increase in $\mathrm{C} 3$ plant water-use efficiency and biomass over glacial to present $\mathrm{CO}_{2}$ concentrations. Nature 361, 61-64.

Poole, I., van Bergen, P.F., 2002. Carbon isotope ratio analysis of organic moieties from fossil mummified wood: establishing optimum conditions for off-line pyrolysis extraction using GC/MS. Rapid Commun. Mass Spectrom. 16, 1-6.

Poole, I., van Bergen, P.F., Kool, J., Schouten, S., Cantrill, D.J., 2004. Molecular isotopic heterogeneity of fossil organic matter: implications for $\delta^{13} \mathrm{C}_{\text {biomass }}$ and $\delta^{13} \mathrm{C}_{\text {palaeoatmosphere proxies. Org. Geo- }}$ chem. $35,1261-1274$. 
Sarkanen, K.V., Ludwig, C.H. (Eds.), 1971. Lignins. Occurrence, Formation, Structure and Reactions. Wiley-Interscience, New York.

Sass-Klaassen, U., Poole, I., Wils, T., Helle, G., Schleser, G.H., van Bergen, P.F., 2004. The use of stable isotope dendrochronology for environmental interpretations from growth ring patterns in subfossil bog oaks. IAWA J. 26, 121-136.

Schneider, W., 1969. Cuticulae dispersae aus dem 2. Lausitzer Flöz (Miozän) und ihre fazielle Aussage. Freiberg. Forsch.-H. C 222, $1-75$.

Schneider, W., 1978. Zu einigen Gesetzmäßigkeiten der faziellen Entwicklung im 2. Lausitzer Flöz. Z. angew. Geol. 24, 125-130.

Schneider, W., 1992. Floral successions in Miocene swamps and bogs of Central Europe. Z. Geol. Wiss. 20, 555-570.

Smith, B.N., Epstein, S., 1971. Two categories of ${ }^{13} \mathrm{C} /{ }^{12} \mathrm{C}$ ratios for higher plants. Plant Physiol. 47, 380-384.

Spiker, E.C., Hatcher, P.G., 1987. The effects of early diagenesis on the chemical and stable carbon isotopic composition of wood. Geochim. Cosmochim. Acta 51, 1385-1391.

Standke, G., Rascher, J., Strauss, C., 1992. Relative sea-level fluctuations and brown coal formation around the Early-Middle Miocene boundary in the Lusatian Brown Coal District. Geol. Rundsch. 82, 295-305.

Stuiver, M., Braziunas, T.F., 1987. Tree cellulose ${ }^{13} \mathrm{C} /{ }^{12} \mathrm{C}$ isotope ratios and climate change. Nature $328,58-60$.

van Bergen, P.F., Poole, I., 2002. Stable carbon isotopes of wood: a clue to palaeoclimate? Palaeogeog. Palaeoclimatol. Palaeoecol. 180, 31-45.

van Bergen, P.F., Collinson, M.E., Hatcher, P.G., de Leeuw, J.W., 1994. Lithological control on the state of preservation of fossil seed coats of water plants. Org. Geochem. 22, 683-702.

van Bergen, P.F., Blokker, P., Collinson, M.E., Sinninghe Damsté, J.S., de Leeuw, J.W., 2004. Structural biomacromolecules in plants: what can be learnt from the fossil record? In: Hemsley, A.R., Poole, I. (Eds.), Evolution of Plant Physiology, Linnean Society Symposium Series, vol. 21. Elsevier, Amsterdam, pp. $133-154$

Woodruff, F., Savin, S.M., 1991. Mid-Miocene isotope stratigraphy in the deep-sea: high resolution correlations, paleoclimatic cycles, and sediment preservation. Paleoceanography 6, 755-806. 